\title{
On the spatial nature of institutions and the institutional nature of personal networks in the Spanish Atlantic
}

\author{
Regina Grafe \\ Chair in Early Modern History, Dept of History and Civilisation, European University Institute, Via Boccaccio 121, 50133 Firenze, Italia
}

\begin{abstract}
Submitted: 20 April 2014. Accepted: 15 May 2014
ABSTRACT: Studies of commercial, cultural and political networks in the Atlantic tend to juxtapose the soft ties of networks to the hard rules of imperial law and trade regulation. The implicit or explicit assumption has been that networks in the Spanish Atlantic served primarily as an antidote to the organisation of the empire and broke out of its spatial boundaries. Networks stood for fluidity, as opposed to the static structures of state and church. This article argues in contrast that networks not only were institutions, but that the empire's institutions were (mostly) networks. It uses the case of the English Atlantic networks operating in northern Spain in the first half of the seventeenth century to show how our interpretation of the interactions between merchant networks and political institutions is transformed when we break up the supposed dichotomy between the two.
\end{abstract}

KEYWORDS: Networks; formal and informal institutions; 17th century; English merchants; Basque Country; consulados

Citation / Cómo citar este artículo: Grafe, Regina(2014). "On the spatial nature of institutions and the institutional nature of personal networks in the Spanish Atlantic". Culture \& History Digital Journal, 3(1): e006. doi: http://dx.doi.org/10.3989/ chdj.2014.006

RESUMEN: Sobre la naturaleza espacial de las instituciones y la naturaleza institucional de las redes personales en el Atlántico Español.- Los estudios de las redes comerciales, culturales y políticas en el Atlántico suelen contrastar los lazos débiles de las redes con las reglas firmes de las leyes y regulaciones de comercio imperiales. Se presume implícita o explícitamente que en el ámbito del Atlántico español las redes funcionaron fundamentalmente como antídoto de la organización del imperio trascendiendo sus limitaciones espaciales. Las redes se asocian con fluidez, opuestas a las estructuras estáticas del estado y de la iglesia. En este artículo sugerimos que las redes no solamente eran instituciones, sino también que las instituciones imperiales se deberían considerar como redes. Con el objetivo de demostrar cómo nuestras interpretaciones de las interacciones entre redes mercantiles e instituciones cambian si rompemos con la idea de una dicotomía entre las dos se analiza el caso de las redes atlánticas inglesas que se establecieron en el norte de España en la primera mitad del siglo XVII.

PALABRAS CLAVE: redes; instituciones formales e informales; siglo XVII; mercaderes ingleses; País Vasco; consulados

Copyright: (C) 2014 CSIC. This is an open-access article distributed under the terms of the Creative Commons AttributionNon Commercial (by-nc) Spain 3.0 License.

The rise of Atlantic history and that of a distinct literature that could be described as the history of networks coincide broadly in time from the late 1990s onwards. The former was in its origin a thoroughly Anglo American enterprise and at least in part rightly criticised as such (Hancock, 1995; Greene and Morgan, 2009; Bailyn,
2005; Games, 2008). Cynical observers argued from its inception that Atlantic History especially as practiced in North American academia was a rear guard fight of historians of the nation state against the rise of global, world and transnational history. At a time when many history departments looked to diversify their traditionally heavily US focused faculties, Atlantic History was charged with being just one way, in which North- 
Americanists could reinvent themselves and find a new raison d'être.

To many scholars' surprise, Atlantic history turned out to be too dynamic to remain in its original habitat. David Armitage's widening of the concept into cis-Atlantic, trans-Atlantic and circum-Atlantic Histories might have struck some historians as one concept too many. Yet, it also beautifully illustrated that once historians had started to think outside traditional national boxes, there was no turning back. Cis-Altantic crossings, comparisons either side of the trans-Atlantic space and the history of circumAtlantic peoples in the Americas, Africa and Europe became the subjects of studies that now also included Spanish, Portuguese, French and Dutch speakers. Even more recently historians have begun to give (over-)due attention to Africans in the Atlantic as actors and not just as nameless objects of the middle passage (Armitage, 2002). The Atlantic was an open system that contained, but also broke out of national, imperial and commodity based subsystems (Pietschmann, 2002). If Atlantic history was an attempt to save US and British national historians from the challenges of globalisation it was a resounding failure. The Genie of Clio has refused to go back into the bottle of the reified nation state of old, no matter how many historians trained in the old ways wish it would. (Bell, 2013).

The historiography on networks has had a more variegated lineage but most strands of it are intimately linked to the history of the Atlantic. Mercantile networks have had pride of place in studies of trans-Atlantic connections long before the label Atlantic history was applied (Liss, 1983; FernándezPérez, 1997; Lamikiz, 2010; Ewert and Selzer,2001). While in the Anglophonehistoriography studies of diasporas, i.e. religious, linguistic and/or ethnic minorities, abound in Atlantic history, in the Iberian case those have become prominent only more recently (Trivellato, 2009; Zahedieh, 2010). Obviously the official requirement for participation in the carrera de Indias of being a natural of the kingdom of the Spains meant that traders from elsewhere had to integrate into the Seville/Cadiz networks (Álvarez Nogal, 2011). Closed networks based on internal cohesion of a religious or linguistic or proto national minority, say the Flemish or Dutch traders at Seville, were always limited by their having to work hand in hand with merchants of the carrera, or at least with a native testaferro. (Crespo Solana, 2011). At the same time, the role played by Basque, Navarrese and later Catalan mercantile networks of common provenance has long been acknowledged (Priotti, 1996). The outsized role of alignments along lines of peninsular origins in Mexico has been stressed yet again by recent studies of the eighteenth century (Stein and Stein, 2009; 2000;2003). At the same time, who was a vecino (citizens) or a natural (vassals of the Spanish kings) was only in exceptional cases a matter of legal norms. Most of the time, acting like a vecino constituted sufficient proof to become a vecino in the eyes of local authorities, which were the ones that could confirm the status(Herzog, 2003). The lines between foreigners and locals were therefore also more fluid than often assumed complicating the notion of networks of common provenance further. Meanwhile, research on religious minority networks of converso merchants usually described as the "Portuguese nation" has shed even more light on the hybridity of Iberian societies in the Peninsula, the Americas and Africa (Mark and Silva Horta, 2011; Studnicki-Gizbert, 2007). ${ }^{1}$

The study of Atlantic networks has also transformed how historians understand cultural exchange, the circulation of knowledge, migration and, in particular, political governance in the Hispanic World. Starting from a critique of traditional models of the absolutist state, historians have begun to conceive of monarchical government in early modern Europe as a persistent negotiation between corporate powers, elite networks and the monarch and his councils. Spain's kings ruled through networks of royal administrators and contacts in urban, ecclesiastical and corporate bodies. ${ }^{2}$ The "King's Men" were the faces of a polity that had yet to become a fully sovereign state. Their immersion in local society turned them into the point of contact between powerful elites in historic territories and Viceroyalties in the Americas and Europe on the one hand, and the Monarchy on the other.

The role of these individuals and their personal networks went far beyond the purely administrative. They advanced funds to implement royal policies from naval construction to military levies, and especially the collection of taxes (Harding and Solbes Ferri, 2012; Torres Sánchez, 2002). They supplied troops and negotiated peace. Their rewards came in the form of social advancement as well as pecuniary benefits, asientos and other commercial privileges, and beneficial marriage alliances (Janssens and Yun Casalilla, 2005; Drelichman and Voth, 2014). Their activities raise attention to the less than monolithic nature of the early modern polity and question established interpretations of the relationship between networks and the state in the Spanish Atlantic. Political networks typically relied on patronage and cooperation rather than command. But they were as much part of the state as the councils of the kings.

In the following section this paper will offer some thoughts about the relationship between networks and institutions in the Spanish Atlantic. In Section three it introduces a case study, the transformation of institutions and networks in the northern Spanish Atlantic trade. The radical change in orientation and organisation of the northern wool trade between the sixteenth and seventeenth centuries could indeed be interpreted in a traditional juxtaposition of closed, monopoly based, mercantilist trade organisation in the sixteenth century and more open networks in the seventeenth. However, section four suggests a new interpretation that breaks down the supposed antagonism between networks and institutions. Section five concludes.

\section{II}

In historiography networks are often an answer to the critique of an earlier legalistic institutional history. 
The common thread in studies of commercial, cultural and political networks in the Atlantic is that they tend to juxtapose the soft ties of networks to the hard rules of imperial law and trade regulation. The implicit or explicit assumption has thus been that networks in the Spanish Atlantic served primarily as an antidote to the organisation of empire. Networks stood for fluidity, as opposed to the static structures of state and church. They were vertically integrated, not hierarchical. Merchants collaborated instead of establishing hegemony. They had urban roots and resisted being drawn into territorial state and empire building. They broke open the strict spatial boundaries between incipient nations and across empires. They obstructed, undermined and perverted the attempts of states to regulate and control every aspect of the economy. As the human face of commerce they destabilised strict trade regulations and the power of the mercantilist bureaucrats in the Atlantic world.

In a recent description of the role of the Portuguese nation in Atlantic trade Studnicki-Gizbert sums up this view . "The intimate scale, the number and the geographical spread of houses that composed a mercantile nation precluded the kind of institutionalized and hierarchical coordination characteristic of states and empires" (Studnicki-Gizbert, 2007: 9). And he goes on to explain that

Trade in the early sixteenth-century was deeply multinational in character, a fact that points to the persistence of medieval commercial structures organized around cities rather than nation-states or empires. Whereas the most visible apparatus of sixteenth-century colonial expansion - the institutions of conquest, administration, and conversion - was ultimately organized by the Castilian or Portuguese Crown, enterprise were based in, and articulated around, urban centers (Studnicki-Gizbert, 2007: 27).

Historians have tended to interpret Atlantic networks as the flexible left-overs of late medieval urban trading traditions that skilfully took advantages of the inconsistencies of absolutist drive to regulate every facet of economic and social life. Networks or nations were thus one important reason why "[u]ltimately it proved impossible for the Spanish state to completely harness the roving dynamism of an Atlantic economy in full economic expansion" (Studnicki-Gizbert, 2007: 30). Networks, we are told, were able to take advantage of the early form of capitalism that was well-established at the close of the Middle Ages and which, we are supposed to conclude, was orthogonal to the state-constrained commercial structure of the carrera.

This widely echoed narrative relies on a set of assumptions that are rarely examined in any detail. First, it harks back to a notion of the Spanish Empire as a centralising, powerful, absolutist, imperial machine at least in ambition. Yet, this has long been exposed as deeply problematic. The political organisation of las Españas - contemporaries wisely employed the plural until deep into the $18^{\text {th }}$ century - was that of a polycentric state (Grafe, 2012). Its most salient characteristic was the flat hierarchies of location of power, visible in the processes negotiation between several centres and across the spatial extension of the Spains (Grafe, 2012). The notion that colonial authorities in Oruro executed what the Audiencia in Potosi asked them to do, which in turn followed the command of a viceroy in Lima, who received his instructions from the monarch and Councils in Madrid is clearly erroneous. Officials at all levels and in all branches of the administration were involved in initiating, discussing, assessing and occasionally refusing to apply what we think of formally as royal or viceregal decrees.

Even leading bureaucrats with privileged direct access to the inner circles of the polity were not just the willing executioners of the monarch's wishes. GaschTomas' excellent research on the bargaining about the regulation of the silk trade is exemplary in this context. Institutions in three of the centres of the polycentric reigns, Manila, Mexico and Seville negotiated over the direction of flows of Chinese, Mexican and European silks in the Atlantic and Pacific. Mexican viceroys were initially against an expansion of the Pacific trade. Yet, as soon as the Manila trade had become important for the Mexican merchant community, the viceroys of New Spain became the staunchest allies of the local consulado, eloquently defending Pacific trade against Seville's attempts to restrict it, and the royal hacienda's efforts to tax it (Gasch-Tomas, 2012: 231-239).

In these conflicts the king and his councils were the ultimate arbiter between local elites rather than the source of most of the legislation. This was true as much in the peninsula as in the Americas (Irigoin and Grafe, 2008). Where the exercise of power relied on decentralised networks as the administrators of the Empire, the location of power was dispersed. Legislation, commercial or otherwise, could effectively be initiated in any institution and at every level of the administration. It was often informed by what was deemed necessary in the local context, and where there was resistance, the King's Men, like the viceroy of Mexico, often quite happily impeded the application of locally unacceptable decrees.

On closer examination it turns out that StudnickiGizbert's "institutions of conquest, administration and conversion" should more correctly be described as private networked enterprises of conquest with hardly any involvement of the Monarchy, webs of administrators with surprising degrees of local and regional power of decision-making, and a church that was as much a competitor for power, influence and tax incomes as an ally of the monarchy. The Spanish Empire has often been described as a paper tiger that could not enforce the decrees that flowed to every corner of the Hispanic reigns precisely because networks of foreign or local merchants, unruly administrators or corrupt tax farmers undermined its urge to control. What the recent literature on political networks shows, however, is that it was never meant to be a forceful centralised structure. Instead 
it was a complex administrative web of shared sovereignties and networks of power and influence that ultimately relied on a process of negotiation in the local context.

Second, the polycentric nature of the polity not only contradicted any notion of a centralised, imperial administrative structure but also made sure that there was never much room for mercantilism in early modern Spain (Grafe, 2014). The Spanish commercial system is still regularly described as a quasi "monopoly" by historians. The loose use of the term "monopoly" in this context is at least imprecise, at worst misleading. To take the most famous example, the fleet system of the Carrera de Indias mirrored the traditional organisation of maritime long-distance trade with a staple port (Seville/Cadiz), a convoy system for protection (flotas and galeones) and a privileged position for merchants of the guild (the consulado) who were licenced to participate. However it maintained internal competition between guild members in stark contrast to the English or Dutch, which created proper monopolies through the EIC and VOC.

The licensing system was more effective in guaranteeing a functioning market than early historians of the carrera imagined. ${ }^{3}$ Jeremy Baskes uses the eventual abolition of the system of fleets and staple ports in the late eighteenth century as a way to assess their role. $\mathrm{He}$ argues that merchants' failing attempts to insure the Spanish American trades after the end of convoys and the proclamation of comercio libre in 1778 illustrate that the rationale for convoying and therefore for a staple port had been sound (Baskes, 2013). Insurance could cover maritime risk, i.e shipwrecks or even piracy, equally or better than convoys had done. Yet, the uncertainty of market conditions in the Atlantic resulting from poor information, shallow markets and wartime privateering threatened to cripple commercial activity in the absence of convoys. Indeed, when compulsory convoys were abolished merchants desperately tried to put together their own.

Baskes has concluded that even in the Bourbon period there is little evidence that merchants either in Cadiz or in Mexico enjoyed monopoly rents or acted as a cartel. Others have made a similar argument about the organisation of the carrera in the sixteenth and seventeenth centuries (Álvarez Nogal, 2011). It was not the outcome of the regulatory mania of a mercantilist state but an attempt to enable trade and maintain competitive structures in the face of almost unsurmountable degrees of uncertainty. Regulation was meant to create a market in a condition of market failure not to suppress it.

What emerges from the recent literature on political and commercial networks in the Spanish Atlantic is thus a polity that seems less rigid in its institutional set-up and a regulation of trade that was more responsive to commercial realities than often assumed. In this light the juxtaposition of a supposedly state-sponsored, mercantilist and closed trading system and governance with the flexibility of networks of provenance that ran circles around the cumbersome official system increasingly looks like a smokescreen. But how can we understand the relationship between commercial and political institutions on the one hand and networks on the other without relying on their supposed antagonism?

A look across the disciplinary divide towards the social sciences can help to dissolve the smokescreen. From an economist's perspective all types of associations including nations and other merchant networks were institutions. There are important nuances between the "strength of weak ties" to use Granovetter's path breaking description of networks and that of formalised institutions (Granovetter, 1982). Yet, the strict distinction between institutions (state, church, town, consulado) and networks (of family, religious or provenance ties) makes little sense from a social scientist's perspective. The difference between mercantile networks and the institutions that for example underpinned the carrera de Indias is simply that the former were overwhelmingly informal and the latter formal (Greif, 2005).

Family bounds, nations, diasporas, guilds, consulados, mercantile courts were all institutional responses to what is known as the "fundamental problems of exchange". Participants in exchange had to be willing to commit ex-ante to a business deal and to be willing to comply with the deal ex-post (Greif, 2000). This created on the one hand a credibility problem. How could a merchant in Lima convince a correspondent in Seville or Cadiz that he was going to sell a shipment of goods at the best possible price and remit the entire gain when the merchant in the peninsula had little chance to monitor his correspondent's dealings? On the other hand, this generated a compliance issue. How could the Lima merchant be sure that the Cadiz trader would pay for the wares he send?

Trust was built precisely around informal and formal institutions. The importance of the work of Greif and others is that they have shown the strength and weaknesses of different forms of organisation. Family members were usually trusted more willingly but limited the size of the network. They also often turned out to be not the most able correspondents. Networks based on provenance or socio-religious minority status offered more diversity in terms of points of contact. But they left merchants with serious issues of monitoring and enforcement. Often referred to as "multilateral coalitions" in the economics literature they increased the incentive for members of the network to act in good faith because members were in constant contact by letter. Information about a cheating corresponding might thus travel fast in the entire network. In other words, misbehaviour would be sanctioned not only by the betrayed trading partner but presumably the dishonest trader would be effectively frozen out of the entire network.

Nations and other informal networks were, however, by far not a perfect way of monitoring good behaviour and, if necessary, punishing dishonest conduct. The slow movement of information in early modern trans-Atlantic trade created such high degrees of market uncertainty, 
as Baskes has suggested, that conflict between traders either side of the Atlantic more often than not resulted from the grey zones of trade. While a Mexican merchant might be convinced a correspondent had taken a cut off the sale of a shipment of dyestuffs, the Seville merchant might have genuinely found himself trying to sell in a glutted market. Commercial fraud was rarely a clear cut story complicating the building of trust.

Members of the informal trans-Atlantic networks that kept the Spanish trade going therefore relied on the formal institutions of the mercantile courts of the consulados or those of the temporal and even ecclesiastical courts to protect their property rights. Family and other networks were most of the time not an alternative to the reliance on formal courts but a complement. Greif showed that informal networks such as the medieval Mediterranean Magribi traders could create self-sustaining informal institutions that could effectively govern their group's trade (Greif, 1988). However, it is also clear now that even these Jewish diasporas made use of Muslim courts in certain circumstances (Goldberg, 2012).

To put it another way: informal and formal institutions all provided commitment and enforcement devices that helped to overcome the fundamental problems of trading across long distances. But informal institutions such as networks rarely replaced formal institutions such as courts or merchant guilds altogether. Nor did formal institutions ever fully substitute for informal ones. Instead merchants combined them in complex and often shifting ways (Gelderblom and Grafe, 2010). Flexibility was not a consequence of the fluidity of (informal) networks that could counter the rigid and hierarchical structures of the state's (formal) mercantilist institutions. Instead the complementarity between different forms of institutional structures allowed traders to deal more effectively with the high degrees of uncertainty they faced.

\section{III}

Thinking about formal and informal institutions, networks, merchant guilds and imperial institutions not as antagonistic forms of social, economic, and political organisation implies a methodological challenge to the writing of Atlantic history. If one gives up the juxtaposition of hard rules and soft ties that seems ill-suited for the early modern Spains, one ought to think about actors in overlapping and interacting political and commercial networks rather than in separate political and economic spheres. There will be a need to remain open-minded with regard to the kinds of political and economic actors that one might encounter rather than start say from a particular nation of merchants, as many in economic history have done so far. This section uses a small example as an illustration of what this might mean.

The chosen case is the networks of merchants that connected the northern Spanish Cantabrian Coast - Asturias, the cuatro villas de la mar de Castilla, Vizcaya and Guipúzcoa - with the Americas between the late $16^{\text {th }}$ and the first half of the $17^{\text {th }}$ centuries. Their spatial dimension reached from the Spanish Peninsula to the Americas, North and South, and north-western Europe, initially Flanders and northern France, later England. The cast in this play was on the one hand the well-known set of Hispanic institutions active in regulating and organising trans-Atlantic and European long distance trade. There were the urban institutions of the major ports such as Bilbao, Santander, or San Sebastián/Donosti. The territorial political representations, such as the Juntas of Vizcaya and Guipúzcoa, as well as the king's representatives, the corregidores, played a crucial role. So did the merchant guilds active in northern Spain, the Consulados of Burgos and Bilbao. On the other hand, there were the foreign nations from Flanders, Nantes, and England active in northern Spain as well as networks of northern Spanish traders active in Seville, Flanders and Nantes. More surprisingly, as we will see, these also interacted with networks of English and north American merchants and fisherman as well as converso networks.

Northern Spanish commercial networks have been researched mostly with regard to their indirect participation in the cycle of activity in the Spanish Americas. In terms of goods trade in the sixteenth century they overwhelmingly engaged in an exchange of wool for textiles with Flanders and northern France as well as in the import of food staples into the agriculturally poor northern regions of Spain. Yet, through the Castilian fairs at Medina del Campo, Medina de Rioseco and Villalón they were intimately linked to the fortunes of the Americas trades. Furthermore, especially in the $16^{\text {th }}$ century trade in the north of Castile and the Cantabrian Coast mirrored in terms of its formal and informal institutions those in the better known carrera.

A process of institutional learning between different towns meant that first Bilbao (1511), and a few decades later Seville (1543) followed the example of Burgos (1494) in establishing a merchant guild and commercial court known as Consulado y Casa de Contratación. While Seville imitated the Burgos and Bilbao consulados with regard to commercial arbitration, regulation and the treatment of foreign nations, Bilbao in 1572 adopted a set of ordinances to govern maritime insurance that replicated those developed by Seville, which had more experience in the matter (Grafe, 2005). Both northern Castilian and Basque merchants equally used a structure of mandatory membership in the nación in the most important host towns abroad, first Bruges then Antwerp, just as merchants in Lima and Mexico were joined in consulados. ${ }^{4}$ French, Flemish and English traders in northern Spain in turn had formal representations, consuls and agreements in Burgos and Bilbao. The main trades in wool and cloth were organised in protective convoys, inspirations for the flotas and galeones, and goods were traded at the Castilian fairs, foretelling those at Portobello.

Beyond the obvious parallels in organisation between the northern trades and the American markets, they also 
converged directly at the Castilian fairs as mentioned above. The royal treasury used the fairs as payment fairs, just as merchants did. The additional liquidity in turn allowed northern wool merchants to find the credit they needed to buy wool in forward contracts before the shearing season. The Monarchy's payment made out of American remittances lubricated thus the business of the pre-existing northern Spanish trading networks with Flanders and Nantes and propelled them to unprecedented heights in the 1550 and 60s (Abed al-Hussein, 1982). As is well known, that interdependence also proved to be their undoing. When the royal treasury experienced liquidity problems in the 1570 s it had to renegotiate its debt with its creditors. The temporary stoppage and conversion of short term debt into long-term bonds did little to harm the mostly Genoese creditors. But together with the interruption of trade after the Dutch Republic closed of the Scheldt in 1576 and war with England resumed they did break the neck of the northern wool and cloth trade.

Between the 1580s and the 1620s the once closely knit informal institutions of trade within northern Spain, between the north and the south and with southern Netherlands and France disappeared almost entirely. Networks disintegrated, merchant families redirected their business or left active trade altogether. The Vizcayan and Castilian nations in Antwerp practically disappeared, with many Castilians moving to Rouen (Gelderblom and Grafe, 2010). Formal institutions, the regulations of trade, the mercantile tribunals and guilds of Bilbao and Burgos and even the fairs languished and lost most of their business. When war dealt a severe external shock to the business formal regulation and organisation and informal networks alike did little to lessen the blow. In fact, the opposite was true. Interconnectedness now meant that bankruptcies had domino effects. Across the entire spatial extension of the networks from Antwerp to Bilbao, Burgos, the Castilian Fairs, and Seville shockwaves ran through the system (Phillips and Phillips, 1977).

Historians, including this author, have looked at the collapse of this system as the typical story of a closed trading system, in which corporate bodies with monopoly rights to certain parts of the trade collected rents (Grafe, 2005; Priotti, 1996; 2005; Phillips and Phillips, $1977 ;$ 1982). When the external conditions changed they were unable to adapt quickly. The organisation of trade in the north was one characterised by a geographical specialisation between participating towns, each of which tried to acquire royal privileges that would give it rights to a particular part of the trade. The Burgos consulado had the right to organise the wool fleets to Flanders; the Bilbao consulado the right to a fixed share of that shipping business excluding both foreigners and other Cantabrian towns; credit and tax bills were by privilege of the fairs due in Medina and so on. The trade was regulated by the Monarchy, which was free to give out monopolies, and exclude other participants. The state supported the control of formal institutions over the trade and made it more susceptible to crisis in the process.

When northern trades recovered after the $1620 \mathrm{~s}$ the formal structure and regulations were still in place. But the reality of the new commercial networks could not be more different. Burgos never recovered an active role in the trade, though it made several attempts to expand its privileges in the early 1600s. The Castilian Fairs ceased to have any supra-regional role. Trade became concentrated in Bilbao. The amount of wool shipped through the port by the 1640 s was still only about half of that that had left all northern ports in the frenzied 1560s. But it tripled between the early 1630 s and the mid-1640s returning to levels that had been normal before the boom of the 1550s and $60 \mathrm{~s}$. In a radical break with previous patterns practically all of it, about 1100 tons, went to England. To contextualise the importance of the trade one might add that this amount was equivalent to about 10 percent of England total wool productions and England was a major producer as is well known. A contemporary English pamphlet estimated that the Bilbao trade was worth $£ 250,000$. This made it comparable to the Levant trade usually considered the most lucrative English trade at the time.

The new English Atlantic network was the start of a spectacular recovery of the commercial fortunes of Bilbao and instrumental in propelling it from the position of one of the northern Spanish ports to becoming The northern Spanish port. The return to the general $a d v a$ loram tax raised by its consulado speaks for itself. ${ }^{5}$

Why England? The secret of the sudden recovery of Bilbao's fortunes was a completely new trading network. Spanish wool was in high demand in the English West Country, where the production of lighter New Draperies for local and southern European markets was expanding fast and relied on the unusually high quality of Spanish merino. But English products were not in demand in northern Spain and English merchants were notoriously short of bullion to pay for their purchases. At the same time, West Country merchants were also strongly involved in English North American settlements. The settlers had but one product to sell, dried and salted codfish, known in Spain as bacalao. There was no demand for this in England, but introduced in the Iberian Peninsula by Basque Fisherman since the early $16^{\text {th }}$ century, it found reasonable demand there. Here then were the makings of one of the first really important triangular Atlantic trades.

The networks that underpinned this trade contradict much of how historians think about the Atlantic. To begin with, they encompassed the English and the Spanish Atlantic apparently without much resistance. In the 1640s there were about 45 resident English merchants in Bilbao, a town whose consulado counted around 65 merchant citizens at the time, some of whom were likely ship captains rather than active merchants. In the sixteenth century northern Castilian and Basque merchants had collaborated in networks that reached 


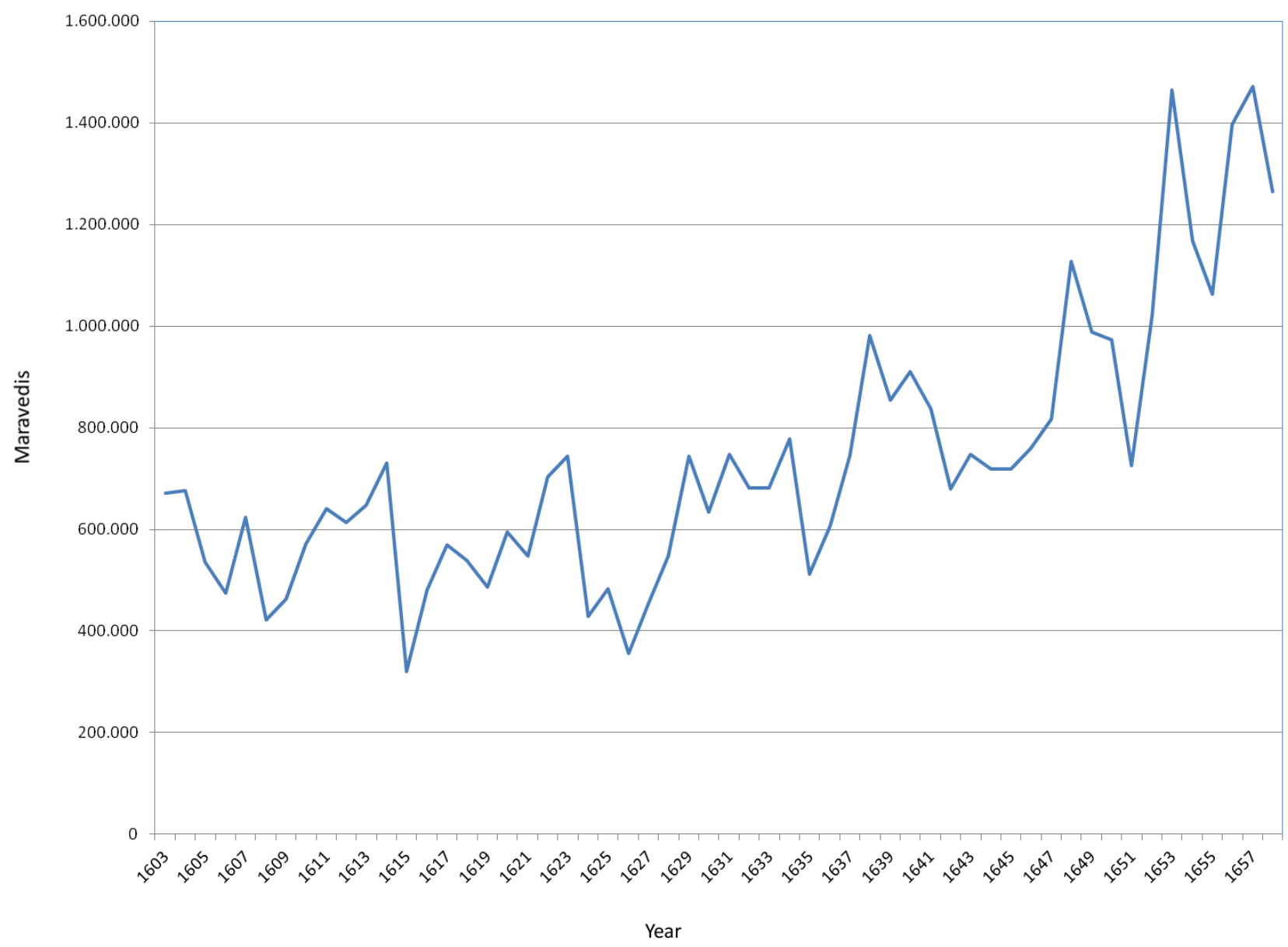

FIGURE I. Bilbao's trade 1603-1658: returns of the Averia (nominal)

Source: AFB/CB, Libro 208, Nr. 1-11, Libro 210, Nr.13-21, Libro 211, Nr.22-33, Libro 212, Nr.34-36 and (Ezkiaga 1977)

from wool producers, via the fairs, and the shipping to the point of the sale in northern Europe. Now the Basques organised the internal supply of wool and the sale of fish. But the English took care of shipping.

Seen from the point of view of the institutional rules in trade this is surprising. According to the Spanish-English peace treaty of 1604 there was no reason why Spanish ships could not go to England. At the same time, the legal preference for Basque shipowners to take cargo before any foreign vessel was allowed to ship it, was still in place. Every English ship master had to ask the town crier to announce his intentions to take a cargo lest a local shipowner objected. ${ }^{6}$ But no shipowner ever did.

In other ways too, the English nation at Bilbao behaved in unusual ways. Most lived for many years, or decades in Bilbao, but very few got married, applied for naturalisation, or bought property. When they did, however, they faced apparently no obstacles. Nor were they keen on formalising the representation of their nation. In the sixteenth century, the relatively few Englishmen on the Cantabrian Coast had been represented by a consul in Bilbao. During the long wars towards the end of the century, the institution had been discontinued, but in the 1640s some English merchants suggested reviving it. ${ }^{7}$ They envisaged for the consul the typical functions: support with legal problems, assurance that the peace treaties were respected, protection against unjust taxation, and organisation of the election of a commission of four English merchants. This commission in turn should take care of the affairs of merchants who died in Cantabria, control the business behaviour of the English, including the rights to check a merchant's books, decide Spanish complaints about the quality of English imports, and finally report to Parliament over the business affairs of the English in Bilbao.

The pamphlet suggesting these changes was countered immediately by some Bilbao merchants with "A humble Answer to a Petition, desiring a regulation of the Biskey-Trade, by a Consull and foure English Factors resident in that place, shewing that thereby we shall not be remedied rather further inconveniences will insue by the same". The title indicated the arguments, namely, that a consul was unnecessary and indeed would 
be harmful. The pamphlet amounted to an astonishing catalogue of the benefits of Bilbao commercial regulation, arbitration and taxation compiled by the English merchants.

They argued that contracts in Spain always stipulated a penalty in case of breach, and that this was sufficient to ensure proper behaviour by Englishmen and Spaniards, (indeed, all contracts did contain a clause that in case of late payment the debtor had to pay a fixed amount, often 500 to 600 maravedies a day, plus the legal costs). Even in the recovery of debt there was no reason for a consul to intervene. Regarding protection against unfair taxes, the authors felt that this was quite unnecessary as well. In principle, this point was covered by the peace treaty of 1604 and if any problem should occur it was preferable to appeal to the Spanish Crown directly. Moreover, there had only been a few problems regarding particular goods sold on in the interior, but there was no problem with direct taxation of trade.

The English were equally happy to appeal to the local justice. They distrusted their fellows more than the Bilbao commercial authorities, and felt that an attempt to create a commission of Englishmen that would have been entitled to check a merchant's books would be abused for commercial ends. For the English counterpetitioners, this sort of commission would just lead to delays and corruption. The Bilbao authorities were the only protection against this behaviour, especially because they never forced a merchant to open his business contacts to the public. Apparently tax collectors, local authorities and the legal services of the consulado tribunal were all behaving nicely towards this large foreign community.

Nor were the English just talking the talk. Rather there is abundant evidence that English merchants were suing compatriots in Spain in cases which could just as easily have been brought before an English court. Legal documentation available in the Bilbao archives of the corregimiento and the consulado contain more than 200 cases, in which members of the English merchant community were involved in some way between 1620 and 1650 . The large majority deals with commercial disputes of some kind, sometimes between two or more English merchants resident in Bilbao, sometimes between an English merchant and a Spaniard. A small number refer to criminal cases, typically the death of a sailor or merchant, beatings or rape. What is curiously missing from all these cases is any indication of protests by English merchants resident in Bilbao against unfair treatment, excesses of the authorities or complaints about the workings of the Spanish justice.

The contrast between the English and Basque networks involved in the new triangular trade with North America and the wool trader networks with Flanders and northern France that had dominated in the sixteenth century could hardly be more pronounced. It would be easy to describe this transformation in the traditional way that juxtaposes state sponsored commercial institutions and monopoly systems in the Spanish dominated sixteenth century networks with an anti-monopolistic attitude of the traders in the English dominated seventeenth century communities. One could write a story of the failure of closed consulado regulations and their mercantilist, anti-capitalist attitudes and the success of the proto-capitalist English Atlantic networks. Indeed, historians of the Basque Country often imply that the exposure of the northern trade of the Dutch and English led to more market oriented attitudes in northern merchant networks.

\section{IV}

A re-evaluation of the evidence in the light of the above discussion about networks and institutions, however, suggests a somewhat altered story. The important difference between the sixteenth and seventeenth century networks is not their spatial extension, here northern Spain, Flanders, and Spanish American silver, there northern Spain, England and North American fish, striking as that might be. Nor is it in the formal institutions regulating trade. The Consulado of Bilbao still had the right to force merchants to first load local ships. The town still had the right to exclude merchants from property ownership, to apply higher taxes to foreigners, to restrict where they could live. The Inquisition still had the right to search every foreign ship coming into port for books (and heretics). Lastly, the informal networks of English and Basque merchants worked largely in similar ways as they had done a century earlier organising around common provenance and family ties.

The fundamental shift was that the Bilbao institutions, urban, ecclesiastical and commercial made no attempt to use their legal rights. This becomes obvious when comparing the situation in Bilbao with other parts of the Spains in the same decades through the protests and enquiries filed by the English Ambassador in Madrid. Complaints about maltreatment of merchants in Andalusia, Portugal, the Levant and the islands bear witness to the problems Englishmen faced elsewhere. But there are practically no complaints from northern Spain. ${ }^{8}$

A closer examination of Inquisition files reveals that few foreigners in the north ever got into trouble about issues of religion. Local Inquisition officials clearly dragged their feet when they were asked to report about the behaviour of the large group of protestant new arrivals in 1632. Otherwise it is hard to explain why they first responded to the request in 1648 (!) and after some serious words from their superiors. The officials from smaller ports in the north reported that all the Englishmen were residing in Bilbao anyway, while the official there vouched for their good behaviour. The only offence to report was that many of them had illegitimate offspring whom they sent to England for education. This was unfortunate because the poor child's soul was lost - but it was unavoidable since the Inquisition could not afford their teaching. ${ }^{9}$ 
Bilbao institutions of all kinds and the political networks that underpinned them evidently made all efforts to accommodate the English. From the early seventeenth century onwards the political, commercial and religious authorities used their power to neutralise anything that they felt could hinder commercial success. They protested against the introduction in 1603 to demand deposits from exporting merchants to be returned if they could prove that they had not traded with the enemy. The Madrid Councils initially delayed in part because of the opposition and in part because of the peace of 1604 (Echevarría Bacigalupe, 1986). ${ }^{10}$

Still, in 1628 the Councils raised the stakes and decreed the introduction of a shipping register. It was to no avail. Antonio de Landaverde, the representative of the assembly of the Señorio de Vizcaya, publicly invoked the pase foral, that is he argued that the province would obey the king, but not execute the order. ${ }^{11}$ The province of Guipúzcoa was equally opposed. ${ }^{12}$ The introduction of registers was stopped until 1641. Then the king's Councils tried again to persuade the northern ports to adopt some measures against the rampant smuggling with enemy ships. The power elites of Vizcaya now changed tactic. They agreed to the introduction of the post of a scrivener, who would take the registers of foreign shipping. But the consulado immediately bought the office for the hefty sum of 5000 ducados making sure that the officeholder would not bother anyone.

This was neither the first nor the last time the commercial networks of Bilbao had used their money and cloud to intervene on behalf of their foreign trading partners. Since 1612, the consulado paid a salary to the officials of the Inquisition, thus reducing the burden the visitations imposed on foreign trade. ${ }^{13}$ Not surprisingly the documentation shows that the charge levied on merchants for the so-called visita de navios was significantly lower in Bilbao than in smaller northern ports and much lower than in other parts of Spain. ${ }^{14}$ The Bilbao consulado also spent much time, effort and ink on keeping the interruption created by the visita to a minimum. Even when forbidden books where found confiscation was about the worst that could happen in Bilbao as it did in the case of an Anglican Bible found in a ship from Chester. ${ }^{15}$ The merchant guilds had a similar attitude to other officials who were initially not directly under its control. In 1660, it paid the royal inspector for contraband for not coming to Bilbao. ${ }^{16}$

The small example of the Atlantic trading networks in Northern Spain in the sixteenth and seventeenth century illustrates nicely why it is problematic to think about networks and institutions in the early modern Hispanic world as antagonistic forms of social organisation, that were possibly complimentary but in any case fundamentally different. The early modern polity was in many ways a network. It is easy to see why merchant dominated urban and consulado institutions in Bilbao should at all times try to favour their protestant trading partners. Yet, so did the provincial institutions, even if the provincial assembly, the juntas, were in fact dominated by rural interests. And so did the Church and Inquisition officials.

Not even the collectors of the royal wool taxes were an exception. Since 1627 the only tax directly to be paid into the royal coffers rather than to the Señorio or the town was controlled by a network of converso entrepreneurs with Castilian, Portuguese and Dutch correspondents. Garcia de Yllan organised collection 1627-39, then passed on the business to Manuel Cortizos y Villasante, who in 1637 sold it to Simon de Fonseca Piña, tax farmer until 1665. All of them were prominent conversos and are often described as members of the Portuguese nation (Studnicki-Gizbert, 2007: 151, 129-133). Garcia de Yllan spent the 1630s writing tracts about how to improve the commercial fortunes of Spain. He praised the role of the consulados, as he would, having worked directly with them in the recovery of the northern wool trade. Control over the taxation of the northern wool trade made commercial sense for the conversos because it helped to transfer funds between their Dutch and Spanish business activities by using England as a stepping point (Kepler, 1976). ${ }^{17}$ Yet, it also meant that they too were part of the state.

\section{V}

The seventeenth century northern commercial networks integrated Basque merchants, wool producers in Castile, English West Country merchants, settlers in North America, and the conversos of the Portuguese nation with their business interests from Madrid and Bilbao to Brazil and Amsterdam. Political, commercial and even ecclesiastical networks were deeply intertwined. What looked like the juxtaposition of powerful institutions with royal privileges in the sixteenth century, the fairs, the consulados and their convoys, the commercial courts, urban restrictions on foreign traders, by the seventeenth century just looked like another set of networks that flexibly engaged with a new group of foreigners. The "institutions of administration" in this particular corner of the Atlantic space were the commercial and religious elites, who crafted, shaped and implemented (or not) most of what is often referred to as the Spanish commercial system. Over time the interests of the commercial networks of local Bilbao or foreign English traders might change, as might those of the political networks in the Basque Provinces, or indeed those of the Sephardic networks. However, the latter like all the others were not the antithesis of the state, they were part and parcel of the very same polity. Networks were institutions and early modern institutions were at their foundations always informal networks.

\section{NOTES}

1. Curiously, though, much less research has been done on conversos who remained in the Spanish reigns. For an exception, see Schreiber, 1994. 
2. One of the first to think about the absolutist state as a networked state was Kettering, 1986. For Spain see Yun Casalilla, 2009.

3. This is partly due to the extraordinary influence of Clarence Henry Haring, "Trade and Navigation between Spain and the Indies in the Time of the Hapsburgs" (Harvard University Press, 1918). Haring's book was translated into Spanish and repeatedly reprinted until 1984.

4. The comparison here is not perfect, the naciones in Antwerp were effectively outposts of the Bilbao and Burgos consulados, while the American guilds were independent. But the important point is that guilded structures dominated in both cases.

5. The charge was a 1 maravedi per ducado, that is $1 / 375^{\text {th }}$ of value. For details see Grafe, 2005: 102.

6. AFB, Corr., Leg.1126/085. See also AHPV, Leg.4730/Enc9/s.f., AHPV/Enc10/s.f. See also Teofilo Guiard Larrauri, Historia Del Consulado De Bilbao Y Casa De Contratación De Bilbao Y Del Comercio De La Villa (1511-1699), Vol I (Bilbao: Jose de Astuy, 1913). Vol.I, 62-4.

7. British Library (BL), 712.g.15/9.

8. See e.g. AHN, Estado, libro 347.

9. AHN, Inquisición, legajo 3645.

10. AFB/CB061, No. 15.

11. AFB/CB, libro 065, No. 59 and AFB/CB, Libro 061, No.4. "yo en nombre del dho senorio con el respecto devido obedezco la dha Prematica como mandado de nro Rey y senor natural. Pero enquanto eso puede ser en qualquiera manera contra los dhos nros fueros por las razones dhas, suplico con toda humildad deella para ante su Real persona, y de ella abaxo para ante los senores del consejo suppremo de Justicia y donde mejor pueda y deva. y contradigo le execucion y cumplimiento de la dha Real prematica en todo lo prejudicial [...]"

12. AHN, Estado, libro 347d.

13. Initially, it was decided that the three officials would get 2,000 reales per year but the consulado later decided that this was too much. In 1615, it decided to pay 50 ducados (550 reales) for the ships from Nantes and agreed on tariffs for other goods. AFB/CB, libro 451, f.xCvi and Cxx,ff. See also the accounts for 1619/20 and 1620/21, AFB/CB, caja 153, No. 28 and No. 27 (old classmark).

14. AHN, Inquisición, legajos 3644 and 3645.

15. AHN, Inquisición, legajo 3645, registro de la visita de navíos en Bilbao, July 1612.

16. AFB/CB, libro 206. The consulado paid 16,350 reales (silver), 9,000 of which were paid for by English merchants. They also paid individually the highest amount.

17. First documented this trade but thought it was caused by English drawbacks

\section{REFERENCES}

Abed al-Hussein, F. H. (1985) "Trade and Business Community in Old Castile. Medina Del Campo, 1500-1575“. Unpubl. Ph.D., University of East Anglia.

Alvarez-Nogal, C. (2011) "Mercados o Redes de Mercaderes: El Funcionamiento de la Feria de Portobelo". In Redes y Negocios Globales en el Mundo Ibérico, Siglos XVI-XVIII, edited by Boettcher, N., Hausberger, B. and Ibarra, A., Iberoamericana Vervuert, Madrid and Frankfurt: 53-86.
Armitage, D. (2002) "Three Concepts of Atlantic History". In The Bristish Atlantic World, edited by Houndmills, P. and Macmillan, B., Houndmills, Palgrave Macmillan, Basingstoke, Hampshire, New York: 11-27.

Bailyn, B. (2005) Atlantic History: Concept and Contours. Harvard University Press, Cambridge.

Baskes, J. (2013) Staying Afloat: Risk and Uncertainty in Spanish Atlantic World Trade, 1760-1820. Stanford University Press, Stanford, California.

Bell, D. A. (2013) "This Is What Happens When Historians Overuse the Idea of the Network". In New Republic. (http://www. newrepublic.com/article/114709/world-connecting-reviewed-historiansoveruse-network-metaphor (accesed October 25 2013).

Candido, M. P. (2013) An African Slaving Port and the Atlantic World: Benguela and its Hinterland. Cambridge University Press, New York.

Cardim, P. (2012) Polycentric Monarchies: How Did Early Modern Spain and Portugal Achieve and Maintain a Global Hegemony? Sussex Academic Press, Brighton; Portland.

Crespo Solana, A. (2011) "Dutch Merchant Networks and the Trade with the Hispanic Port Cities in the Atlantic (1648-1778)". In Redes y Negocios Globales en el Mundo Ibérico, Siglos XVI-XVIII, edited by Boettcher, N., Hausberger, B. and Ibarra, A., Iberoamericana Vervuert, Madrid, Frankfurt: 107-142.

Drelichman, M. and Voth, H. J. (2014) Lending to the Borrower from Hell: Debt, Taxes, and Default in the Age of Philip II. Princeton University Press, Princeton.

Echevarría Bacigalupe, M. A. (1986) "Un Notable Episodio en la Guerra Económica Hispano-Holandesa: El Decreto Gauna (1603)". Hispania XLVI, No. 162: 57-97.

Ewert, U. C. and Selzer, S. (2001) "Verhandeln Und Verkaufen, Vernetzen Und Vertrauen. Ueber Die Netzwerkstruktur Des Hansischen Handels'. Hansische Geschichtsblaetter 119: 135-162.

Ezkiaga, P. (1977) "Bilboko Merkatalgoa XVII. Mendean (Apunteak)". Unpubl. Ph.D., Deusto.

Fernández Pérez, P. (1997) El Rostro Familiar de la Metrópoli. Redes de Parentesco y Lazos Mercantiles en Cádiz, 1700-1812. Siglo XXI, Madrid.

Ferreira, R. A. (2012) Cross-Cultural Exchange in the Atlantic World: Angola and Brazil During the Era of the Slave Trade. Cambridge University Press, New York.

Games, A. R. A. (2008) Major Problems in Atlantic History: Documents and Essays. Houghton Mifflin, Boston

Gasch-Tomas, J. L. (2012) "Global Trade, Circulation and Consumption of Asian Goods in the Atlantic World. The Manila Galleons and the Social Elites of Mexico and Seville (1580-1640)". Unpublished $\mathrm{PhD}$, European University Institute.

Gelderblom, O. and Grafe, R. (2010) "The Rise, Persistence and Decline of Merchant Guilds. Re-Thinking the Comparative Study of Commercial Institutions in Pre-Modern Europe". Journal of Interdisciplinary History XL, No. 4: 477-511.

Goldberg, J., (2012) Trade and Institutions in the Medieval Mediterranean: The Geniza Merchants and Their Business World. Cambridge University Press, New York.

Grafe, R. (2005) Entre el Mundo Ibérico y el Atlántico. Comercio y Especialización Regional, 1550-1650. Diputación Foral de Bizkaia, Bilbao.

Grafe, R. (2012) Distant Tyranny. Markets, Power and Backwardness in Spain 1650-1800. Princeton University Press, Princeton.

Grafe, R. (2014) "Polycentric States: The Spanish Reigns and the "Failures" of Mercantilism". In Mercantilism Reimagined: Political Economy in Early Modern Britain and its Empire, edited by Stern, P. and Wennerlind, C., Oxford University Press, New York.

Grafe, R. (2014, in press) "Polycentric State-Building and Fiscal Systems in Spain and Europe 1650-1800". In Ressources Publiques Et Construction Etatique En Europe, edited by Beguin, K., Paris.

Granovetter, M. (1982) "The Strength of Weak Ties: A Network Theory Revisited". In Social Structure and Network Analysis, edited by Marsden, P. and Nan, L., Sage Publications, Beverly Hills: 105-130. 
Greene, J. P. and Morgan, P. D. (2009) Atlantic History: A Critical Appraisal, Reinterpreting History. Oxford University Press, New York.

Greif, A. (1989) "Reputation and Coalitions in Medieval Trade: Evidence on the Maghribi Traders". Journal of Economic History 49, No. 4: 857-882.

Greif, A. (2000) "The Fundamental Problem of Exchange: A Research Agenda in Historical Institutional Analysis". European Review of Economic History 4: 251-284.

Greif, A. (2005) "Commitment, Coercion, and Markets: The Nature and Dynamics of Institutions Supporting Exchange". In Handbook of New Institutional Economics, edited by Ménard, C. and Shirley, M. M., Springer, Dordrecht: 727-786.

Guiard Larrauri, T. (1913) Historia del Consulado de Bilbao y Casa de Contratación de Bilbao y del Comercio de la Villa (1511-1699). Editorial La Gran Enciclopedia Vasca, Bilbao, 4 vols.

Hancock, D. (1995) Citizens of the World: London Merchants and the Integration of the British Atlantic Community. Harvard University Press, Cambridge.

Harding, R. and Solbes Ferri, S. (editors), (2012) The Contractor State and Its Implications: 1659-1815. Universidad de Las Palmas de Gran Canarias, Servicio de Publicaciones, Las Palmas de Gran Canaria.

Haring, C. H. (1918) Trade and Navigation between Spain and the Indies in the Time of the Hapsburgs. Harvard University Press, Cambridge.

Herzog, T. (2003) Defining Nations: Immigrants and Citizens in Early Modern Spain and Spanish America. Yale University Press, New Haven.

Irigoin, A. and Grafe, R. (2008) "Bargaining for Absolutism. A Spanish Path to Empire and Nation Building". Hispanic American Historical Review 88, No. 2: 173-210.

Janssens, P. and Yun Casalilla, B. (2005) European Aristocracies and Colonial Elites: Patrimonial Management Strategies and Economic Development, 15th-18th Centuries. Aldershot, Hants, UK; Burlington, VT.

Kepler, J. S. (1976) The Exchange of Christendom: The International Entrepot at Dover 1622-1651. Leicester University Press, Leicester.

Kettering, S. (1986) Patrons, Brokers, and Clients in SeventeenthCentury France. Oxford University Press, New York.

Lamikiz, X. (2010) Trade and Trust in the Eighteenth-Century Atlantic World: Spanish Merchants and their Overseas Networks. Boydell Press, Woodbridge, Suffolk, UK; Rochester, NY.

Liss, P. K. (1983) Atlantic Empires. The Network of Trade and Revolution, 1713-1826. Johns Hopkins University Press, Baltimore.
Mark, P. and Horta, J. d. S. (2011) The Forgotten Diaspora. Jewish Communities in West Africa and the Making of the Atlantic World. Cambridge University Press, Cambridge, New York.

Phillips, C. R. (1982) “The Spanish Wool Trade, 1500-1780". Journal of Economic History 42, No. 4: 775-795.

Phillips, C. R. and Phillips, W. D. (1977) "Spanish Wool and the Dutch Rebels: The Middelburg Incident of 1574". American Historical Review 82, No. 2: 312-330.

Pietschmann, H. (editor), (2002) Atlantic History: History of the Atlantic System 1580-1830. Vandenhoeck \& Ruprecht, Goettingen.

Priotti, J. P. (1996) "Mercaderes Vascos y Castellanos en Europa durante el Siglo XVI: Cooperaciones y Rivalidades". In Castilla y Europa. Comercio y Mercaderes en los siglos XIV, XV y XVI, edited by Casado Alonso, H., Diputación Provincial de Burgos, Burgos: 265-283.

Priotti, J. P. (2005) Bilbao y sus Mercaderes en el Siglo XVI. Génesis de un Crecimiento. Diputación Foral de Vizcaya, Bilbao.

Schreiber, M. (1994) Marranen in Madrid 1600-1670. F. Steiner, Stuttgart.

Stein, B. H. and Stein, S. J. (2009) Edge of Crisis. War and Trade in the Spanish Atlantic, 1789-1808. Johns Hopkins University Press, Baltimore.

Stein, S. J. and Stein, B. H. (2009) Silver, Trade, and War. Spain and America in the Making of Early Modern Europe. Johns Hopkins University Press, Baltimore.

Stein, S. J. and Stein, B. H. (2003) Apogee of Empire: Spain and New Spain in the Age of Charles III, 1759-1789. Johns Hopkins University Press, Baltimore.

Studnicki-Gizbert, D. (2007) A Nation Upon the Ocean Sea: Portugal's Atlantic Diaspora and the Crisis of the Spanish Empire, 1492-1640. Oxford University Press, New York.

Torres Sánchez, R. (2002) "El Gran Negociode la Época, la Provisión de Víveres al Ejército por Francisco Mendinueta (1744-1763)". In Francisco Mendinueta: Finanzas y Mecenazgo en la España del Siglo XVIII, edited by Aquerreta, S. Ediciones Universidad de Navarra, Pamplona.

Trivellato, F. (2009) The Familiarity of Strangers. The Sephardic Diaspora, Livorno and Cross-Cultural Trade in Early Modern Europe. Yale University Press, New Haven, London.

Yun Casalilla, B. (2009) Las Redes del Imperio: Élites Sociales en la Articulación de la Monarquía Hispánica, 1492-1714. Marcial Pons, Madrid.

Zahedieh, N. (2010) The Capital and the Colonies: London and the Atlantic Economy, 1660-1700. Cambridge University Press, Cambridge, New York. 